\title{
Long term effect of Organic, Integrated and Inorganic Nutrient Management Practises on Soil Properties in a Vertisol
}

\author{
Praveen Karikatti ${ }^{1}$, S. N. Bhat $^{1^{*}}$, S. R. Balanagoudar ${ }^{1}$, B. G. Mastanareddy ${ }^{2}$, \\ H. Veeresh ${ }^{1}$ and Satyanarayana Rao $^{2}$
}

${ }^{1}$ Department of Soil Science and Agril. Chemistry, ${ }^{2}$ Department of Agronomy, University of Agricultural Sciences, Raichur- 584 104(Karnataka), India

*Corresponding author

\section{Keywords}

Organics, Long term effect, Physical and chemical property of soil

Article Info

Accepted:

22 December 2019 Available Online: 20 January 2020
A B S T R A C T

A long term experiment on paddy for eleven years ( 2005-06 to 2016-17) was conducted on a clayey textured Vertisol at Agricultural Research Station, Gangavati, UAS, Raichur to compare the influence of organic and conventional farming systems on soil physical, chemical and biological properties of soil with the following treatments viz., $\mathrm{T}_{1}: 100 \% \mathrm{~N}$ through organics, $\mathrm{T}_{2}: 75 \% \mathrm{~N}$ through organics, $\mathrm{T}_{3}$ : Integrated $\mathrm{N}$ management $(50 \%$ $\mathrm{N}$ through organics \& $50 \% \mathrm{~N}$ through organics), $\mathrm{T}_{4}: 100 \% \mathrm{~N}$ through inorganics along with FYM @ 7 t/ha, $\mathrm{T}_{5}: 100 \%$ RDF (150: 75:75 $\mathrm{kg} / \mathrm{ha}$ ).The experiment was laid out in a Randomized Block Design and treatments were replicated four times. Results revealed there was no such variation in physical properties of soil, particularly, bulk density and penetration resistance but maximum water holding capacity of soil differed significantly with different farming systems. The higher organic carbon content of 0.85 per cent was recorded due to 100 per cent substitution of $\mathrm{N}$ to paddy crop through organics. Available $\mathrm{N}\left(228 \mathrm{~kg} / \mathrm{ha}^{-1}\right)$ was higher in treatment containing complete organic farming treatment whereas higher available $\mathrm{P}$ and $\mathrm{K}\left(55.87 \& 688.4 \mathrm{~kg} / \mathrm{ha}^{-1}\right)$ in treatment receiving 100 per cent $\mathrm{N}$ through in-organics along with FYM @ 7 t/ha. The DTPA extractable micronutrients $\mathrm{Fe}, \mathrm{Mn}, \mathrm{Zn}$ and $\mathrm{Cu}$ were significantly higher in treatment consisting of 100 per cent organics $(7.4,4.43,0.73$ and $0.56 \mathrm{ppm}$, respectively). 


\section{Introduction}

Increased/ indiscriminate use of chemical fertilizers and pesticides during green revolution period resulted in several harmful effects on soil, water and air causing their pollution. This has reduced the productivity of the soil by deteriorating soil health in terms of soil fertility and biological activity. The excess/indiscriminate use of pesticides has led to the entry of harmful compounds into food chain, death of natural enemies and development of resurgence/resistance to pesticides.. It is believed that organic farming can solve many of these problems as this system is believed to maintain soil productivity and pest control by enhancing natural processes and cycles in harmony with environment. In this regard, a study was undertaken to know the impact of different farming system approaches on soil health over a period of 11 years.

\section{Materials and Methods}

The present investigation entitled "long term effect of organic, in-organic and integrated nutrient management practices on soil quality parameters" was studied in a Vertisol of TBP command area where paddy (var. BPT-5204) being grown since 2005-06 on a fixed location at ARS, Gangavathi, UAS, Raichur ( Northern Dry Zone, Zone 3) of Karnataka state. Experiment consisted of 5 treatments, which were replicated four times and laid out in RCBD design. The treatments were: $\mathrm{T}_{1}$ : $100 \% \mathrm{~N}$ through organics, $\mathrm{T}_{2}: 75 \% \mathrm{~N}$ through organics, $\mathrm{T}_{3}$ : Integrated $\mathrm{N}$ management $(50 \% \mathrm{~N}$ through organics \& 50 $\% \mathrm{~N}$ through organics), $\mathrm{T}_{4}: 100 \% \mathrm{~N}$ through in-organics along with FYM @ 7 t/ha, T $5: 100$ \% RDF (150: 75:75 kg/ha). The experimental soil characteristics were: slightly alkaline $(\mathrm{pH}$ 8.1); non-saline (EC $0.45 \mathrm{dS} / \mathrm{m}$ ); and medium soil organic carbon $(0.65 \%)$ content. Soil available $\mathrm{N}$ was low $(220 \mathrm{~kg} / \mathrm{ha})$; available phosphorus was medium (45.0 kg P2O5/ha); available potassium was high $(650 \mathrm{~kg} \mathrm{~K} 2 \mathrm{O}$ /ha) .The organic sources used were: crop residue, FYM, neem cake and poultry manure. The recommended dose of inorganic fertilizers were given at the rate of 150:75:75 $\mathrm{kg} \mathrm{N}, \mathrm{P}_{2} \mathrm{O}_{5}, \mathrm{~K}_{2} \mathrm{O} / \mathrm{ha}$ and $25 \mathrm{~kg} \mathrm{ZnSO}_{4} / \mathrm{ha}$ were applied. Nitrogen was given in three equal splits at basal, maximum tillering and panicle initiation stages, while $\mathrm{P}, \mathrm{K}$ and $\mathrm{Zn}$ were given as basal doses only. Through organics (crop residues, FYM, poultry manure \& neem cake), $\mathrm{N}$ dose was adjusted to recommended level based on their moisture content and ' $\mathrm{N}$ ' concentration on dry weight basis. Recommended cultural practises were followed. Soil quality parameters were recorded as per the standard procedures outlined by Piper (1966), Jackson ( 1973) and Sadasivam and Manickam (1992).

Physical properties of soil as influenced by different farming system are presented in Table 1.

\section{Bulk density and Soil penetration resistance $(\mathbf{P R})$}

Bulk density and penetration resistance of soil did not vary significantly with application of the organic or inorganic sources of nutrients. However, numerically lower bulk density and penetration resistance value was found in the treatment which received nitrogen through organic sources compared to those received the nutrients through in-organic sources. The similar findings were also reported Boydaş and Turgut (2007) and Katsvairo et al.,( 2002).

\section{Maximum water holding capacity}

Maximum water holding capacity (MWHC) of soil differed significantly among different treatments at surface and subsurface. Significantly higher MWHC values recorded in treatment which received 100 per cent nitrogen through organic sources alone 
(T1:74.62\%) compared to that received 100 per cent nitrogen through in-organics (T5:.71.87\%). These results are in conformity with findings of Bhatia and Shukla (1982) and Acharya et al. (1988) who observed improvement in water holding capacity of soil due to addition of organic manures compared to only inorganic fertilizer application. Application of vermicompost @ 5 tonnes per ha increased MWHC compared to control as reported by Jadhav et al. (1993). Build up of soil organic matter and improvement in soil structure by application of residue and FYM to soil were responsible for significant increase in water holding capacity of soil (Sharma et al., 2000).

Chemical parameters of soil as influenced by different farming system are presented in table 2 .

\section{Soil reaction and electrical conductivity}

The $\mathrm{pH}$ and soluble salt content of soil was unaffected significantly by different treatments, consisting of supply of nitrogen through 100, 75 and 50 per cent through organics (T1, T2 and T3) and those supplying 100 per cent $\mathrm{N}$ through inorganic sources.

\section{Organic carbon $(\mathrm{OC})$}

Irrespective of the treatments, OC content was higher at surface and appears to decline as the depth increase (Table 2 and fig. 1). The content of OC at surface and subsurface soils in the treatment which received 100, 75 and 50 per cent nitrogen through organics recorded higher OC values (T1: 0.85 and 0.75 $\%, \mathrm{~T} 2: 0.7$ and $0.7 \%$ and $\mathrm{T} 3: 0.68$ and $0.6 \%$, respectively) were higher than that received the $\mathrm{N}$ through inorganic sources (T5:0.55 and $0.45 \%$, respectively). Continuous application of chemical fertilizers for rice over a period of ten years lowered the OC content of soil by about 54.5 per cent. The increase in organic carbon content of soils under organic farming was quite obvious since the carbonaceous materials contribute to soil organic carbon after their decomposition. These observations are in agreement with the findings of Grawel et al. (1981), Sinha et al. (1983), Kaushik et al. (1984), Gupta et al. (1988) and Bhandari et al. (1992). Addition of higher quantity of organic manures and longer period of organic farming practice were responsible for buildup of organic carbon in soil. A significant increase in organic carbon content of Vertisol after four years of decomposition of organic manure over fertilizer application was observed by Bellakki and Badanur (1994).

The available major nutrient status of soil as influenced by farming system is presented in Table 3 and figure 2 .

\section{Available nitrogen}

Available $\mathrm{N}$ content of soil at both depths differed significantly. The higher $\mathrm{N}$ content of soil recorded in treatment (T1:228.2 and $222.3 \mathrm{~kg} / \mathrm{ha}$ ) which received entire nitrogen through organic sources was on par with all other treatments including that containing recommended dose of fertilizers (T5:210.9 and $184.6 \mathrm{~kg} / \mathrm{ha}$, respectively). However, as par soil test rating available $\mathrm{N}$ status in the soil was found to be in low category $(<280$ $\mathrm{kg} / \mathrm{ha}$ ) in all the treatments. Lower value of available $\mathrm{N}$ in fertilizer treated plot might be due to utilization of applied nitrogen by the crop and probably losses of nitrogen through leaching, volatilization etc. On contrary, application of the organic alone or in combination with inorganic fertilizers maintained higher $\mathrm{N}$ status in soil, because of the fact that direct addition of $\mathrm{N}$ through organics alone or in combination with inorganic fertilizer resulting in slow release of appreciable quantity of $\mathrm{N}$ to soil available $\mathrm{N}$ pool. An increase in available $\mathrm{N}$ by application of vermicompost and FYM was 
also reported by Phule (1993) and Pawar (1996). The increase in available nitrogen due to organic matter application is also attributable to the greater multiplication of soil microbes caused by the addition of organic materials which mineralize organically bound $\mathrm{N}$ to inorganic form (Bellakki and Badanur, 1994).

\section{Available phosphorus}

Available $\mathrm{P}$ status was also differed significantly and the value was higher in the treatment which received $\mathrm{N}$ through inorganic fertilizer along with FYM @ 7t/ha (T4: 55.87 $\mathrm{kg} / \mathrm{ha}$ ) compared to all other treatment including those supplied with organic sources of nutrients (T1:45.6 kg/ha and T2: $40.1 \mathrm{~kg} / \mathrm{ha}$ ) and integration of both organic and inorganic nutrient sources (T3:48.67 $\mathrm{kg} / \mathrm{ha}$ ). The higher available $\mathrm{P}$ recorded with application inorganic fertilizer along with FYM may be due to organic acid released from decomposition of organic sources which might have helped in release of insoluble phosphates from the soil and applied inorganic fertilizers. It is agreement with findings of Singh et al. (1982) who noticed an increase in available phosphorus content of soil due to incorporation of FYM alone or in combination with inorganic fertilizers and attributed it to the enhanced solubilisation of native phosphorus and added phosphorus by the decomposition product of organic manures. Venkateshwarulu (1983) noticed an increase in available phosphorus with the application of organic residues over a period of five years in red soils of Hyderabad. Tandon (1987) attributed the increase in available phosphorus with FYM application to the contribution of $\mathrm{P}$ by the organics to the soil available pool and coating of organic material on sesquioxides which reduces the phosphate fixing capacity of soil. Similar observations were also reported by Bharadwaj and Omanwar (1994).In contrast to soil available $\mathrm{N}$ status, available $\mathrm{P}$ content was found to be much higher than soil test rating of high category (> 55kg/ha) in all the treatments.

\section{Available potassium}

Irrespective of the treatments available $\mathrm{K}$ was highest at surface and observed to decline as depth increases. The $\mathrm{K}$ content of surface soils was higher (T4: $688.4 \mathrm{~kg} / \mathrm{ha}$ ) in the treatment which received recommended dose of inorganic fertilizer along with FYM @ 7 $\mathrm{t} / \mathrm{ha}$ and the lowest $(\mathrm{T} 5: 670.7 \mathrm{~kg} / \mathrm{ha})$ in the treatment which received inorganic fertilizer alone (T5). The higher available $\mathrm{K}$ registered in T4 treatment is due to application of recommended dose of $\mathrm{K}$ fertilizer to paddy crop along with gradual release of $\mathrm{K}$ from the organic sources. Similar observations of increase in available potassium due to addition of organic manures were made by Grawel et al. (1981) and Bharadwaj and Omanwar (1994). Relatively higher available $\mathrm{K}$ content found in treatment which received the nutrients through organic sources (T1 or T2) and integration of organic source along with inorganic sources (T3) compared to that receiving inorganic nutrients source alone (T5). This higher level of available K may be ascribed to greater capacity of organic matter to hold nutrients at the exchangeable surface and thereby reduce $\mathrm{K}$ fixation and thus help greater availability of $\mathrm{K}$ in soil.

\section{DTPA-extractable micronutrients}

The data of DTPA extractable micronutrients in soil ( Table 4) revealed that available $\mathrm{Zn}$, $\mathrm{Fe}, \mathrm{Mn}$ and $\mathrm{Cu}$ in soil, irrespective of the treatments, were above the critical level concentration required for optimum yield in rice $(0.5-0.8,2.5-4.5,1.0$ and $0.2 \mathrm{ppm}$, for $\mathrm{Zn}$, $\mathrm{Fe}, \mathrm{Mn} \& \mathrm{Cu}$, respectively). Application of different organic material recorded comparatively higher available $\mathrm{Zn}, \mathrm{Fe}, \mathrm{Mn}$ and $\mathrm{Cu}$ than rest of the treatments. The 
slightly higher content of $\mathrm{Zn}, \mathrm{Fe}, \mathrm{Mn}$ and $\mathrm{Cu}$ in the treatments consisting of organics is attributed to a formation of stable chalets with organic legends which decrease their adsorption, fixation and precipitation. Organic manures is not only rich source of micronutrients but also provide convenient physical, chemical and biological environment in soil for better nutrient availability. Addition of large quantities of organic manures every year under organic farming practice was the cause for such marked increase in the DTPA-extractable micronutrients.

\section{Microbial population}

The treatment which received fully organic manures had significantly more influence on the population of bacteria, fungi and actinomycetes than fully inorganic application (Table 5 \& fig. 3). The reason behind this could be to the enhanced organic carbon content of the soil as a result of organic manure application as compared to inorganic fertilizers. Besides this, the application of organic manure would have resulted in increased secondary and micronutrients in the soil, which might have helped to increase the microbial population.

Table.1 Physical properties of soil as influenced by farming systems (after 11 years)

\begin{tabular}{|c|c|c|c|c|c|c|c|c|}
\hline \multirow{3}{*}{ Treatment } & \multicolumn{8}{|c|}{ Parameters } \\
\hline & \multicolumn{2}{|c|}{$\begin{array}{l}\text { Bulk Density } \\
\qquad\left(\mathrm{g} \mathrm{cc}^{-1}\right)\end{array}$} & \multicolumn{2}{|c|}{$\begin{array}{l}\text { Porosity } \\
(\%)\end{array}$} & \multicolumn{2}{|c|}{$\begin{array}{c}\text { Maximum water } \\
\text { holding }(\%) \\
\text { capacity }(\%)\end{array}$} & \multicolumn{2}{|c|}{$\begin{array}{c}\text { Penetration } \\
\text { resistance }(\mathrm{MPa}) \\
(\mathrm{MPa})\end{array}$} \\
\hline & $0-20 \mathrm{~cm}$ & $20-40 \mathrm{~cm}$ & $0-20 \mathrm{~cm}$ & $20-40 \mathrm{~cm}$ & $0-20 \mathrm{~cm}$ & $20-40 \mathrm{~cm}$ & $0-20 \mathrm{~cm}$ & $20-40 \mathrm{~cm}$ \\
\hline $\begin{array}{l}\mathrm{T}_{1}: 100 \% \mathrm{~N} \\
\text { through organics }\end{array}$ & 1.29 & 1.32 & 52.45 & 50.66 & 74.62 & 77.60 & 3.82 & 3.84 \\
\hline $\begin{array}{l}\mathrm{T}_{2}: 75 \% \mathrm{~N} \\
\text { through organics }\end{array}$ & 1.31 & 1.36 & 50.66 & 48.01 & 73.82 & 76.27 & 3.92 & 3.92 \\
\hline $\begin{array}{l}\mathrm{T}_{3}: 50 \% \mathrm{~N} \\
\text { through organics } \\
\text { \& } 50 \% \mathrm{~N} \\
\text { through } \\
\text { inorganic }\end{array}$ & 1.32 & 1.37 & 50.09 & 48.30 & 73.32 & 76.92 & 3.61 & 3.86 \\
\hline $\begin{array}{l}\mathrm{T}_{4}: 100 \% \mathrm{~N} \\
\text { through in- } \\
\text { organics and } \\
\text { FYM @ } 7 \mathrm{t} / \mathrm{ha}\end{array}$ & 1.30 & 1.39 & 51.88 & 50.28 & 72.07 & 75.07 & 3.79 & 4.17 \\
\hline $\begin{array}{l}\mathrm{T}_{5}: 100 \% \mathrm{RDF} \\
150: 75: 75 \mathrm{~kg} / \mathrm{ha}\end{array}$ & 1.34 & 1.40 & 50.94 & 48.49 & 71.87 & 73.30 & 4.03 & 4.47 \\
\hline SEm \pm & 0.21 & 0.02 & 0.36 & 0.49 & 0.59 & 0.42 & 0.48 & 0.34 \\
\hline CD@5\% & NS & NS & NS & 1.53 & 1.83 & 1.11 & NS & NS \\
\hline
\end{tabular}


Table.2 Chemical properties of soil as influenced by farming systems (after 11 years)

\begin{tabular}{|c|c|c|c|c|c|c|}
\hline \multirow[b]{2}{*}{ Treatment } & \multicolumn{2}{|c|}{ pH(1:2.5 w/v) } & \multicolumn{2}{|c|}{$E C\left(d S m^{-1}\right)$} & \multicolumn{2}{|c|}{$\mathrm{OC}(\%)$} \\
\hline & $0-20 \mathrm{~cm}$ & $20-40 \mathrm{~cm}$ & $0-20 \mathrm{~cm}$ & $20-40 \mathrm{~cm}$ & $0-20 \mathrm{~cm}$ & $20-40 \mathrm{~cm}$ \\
\hline $\begin{array}{l}\mathrm{T}_{1}: 100 \% \mathrm{~N} \text { through } \\
\text { organics }\end{array}$ & 8.02 & 8.26 & 0.56 & 0.59 & 0.85 & 0.75 \\
\hline $\begin{array}{l}\mathrm{T}_{2}: 75 \% \mathrm{~N} \text { through } \\
\text { organics }\end{array}$ & 7.97 & 8.42 & 0.44 & 0.45 & 0.70 & 0.70 \\
\hline $\begin{array}{l}\mathrm{T}_{3}: 50 \% \mathrm{~N} \text { through } \\
\text { organics \& } \mathbf{5 0} \% \mathrm{~N} \\
\text { through inorganic }\end{array}$ & 7.97 & 7.82 & 0.46 & 0.72 & 0.68 & 0.60 \\
\hline $\begin{array}{l}\mathrm{T}_{4}: 100 \% \mathrm{~N} \text { through in- } \\
\text { organics and FYM @ } 7 \\
\text { t/ha }\end{array}$ & 7.88 & 7.83 & 0.73 & 0.75 & 0.65 & 0.55 \\
\hline $\begin{array}{l}T_{5}: 100 \% \text { RDF, 150: } \\
75: 75 \mathrm{~kg} / \mathrm{ha}\end{array}$ & 7.79 & 7.76 & 0.60 & 0.67 & 0.55 & 0.45 \\
\hline SEm \pm & 0.14 & 0.18 & 0.13 & 0.13 & 0.06 & 0.09 \\
\hline CD@5\% & NS & NS & NS & NS & 0.20 & 0.26 \\
\hline
\end{tabular}

Table.3 Chemical properties of soil as influenced by farming systems (after 11 years)

\begin{tabular}{|c|c|c|c|c|c|c|}
\hline \multirow[b]{2}{*}{ Treatment } & \multicolumn{2}{|c|}{ Available N (kg ha $\left.{ }^{-1}\right)$} & \multicolumn{2}{|c|}{ Available P2O5 $\left(\mathrm{kg} \mathrm{ha}^{-1}\right)$} & \multicolumn{2}{|c|}{ Available K2O $\left(\mathrm{kg} \mathrm{ha}^{-1}\right)$} \\
\hline & $\begin{array}{c}0-20 \\
\mathrm{~cm}\end{array}$ & $\begin{array}{c}20-40 \\
\mathrm{~cm}\end{array}$ & $\begin{array}{c}0-20 \\
\mathrm{~cm}\end{array}$ & $\begin{array}{c}20-40 \\
\mathrm{~cm}\end{array}$ & $0-20 \mathrm{~cm}$ & $\begin{array}{c}20-40 \\
\mathrm{~cm}\end{array}$ \\
\hline $\begin{array}{l}\mathrm{T}_{1}: 100 \% \mathrm{~N} \\
\text { through organics }\end{array}$ & 228.2 & $\begin{array}{c}222 . \\
3\end{array}$ & 45.60 & 43.27 & 684.2 & 668.2 \\
\hline $\begin{array}{l}\mathrm{T}_{2}: 75 \% \mathrm{~N} \\
\text { through organics }\end{array}$ & 226.7 & $\begin{array}{c}193 . \\
1\end{array}$ & 40.10 & 40.10 & 650.5 & 640.5 \\
\hline $\begin{array}{l}\mathrm{T}_{3}: 50 \% \mathrm{~N} \\
\text { through organics } \\
\& 50 \% \mathrm{~N} \\
\text { through inorganic }\end{array}$ & 221.3 & $\begin{array}{c}196 . \\
6\end{array}$ & 48.67 & 45.60 & 686.6 & 675.2 \\
\hline $\begin{array}{l}\mathrm{T}_{4}: 100 \% \mathrm{~N} \\
\text { through in- } \\
\text { organics and } \\
\text { FYM @ } 7 \mathrm{t} / \mathrm{ha}\end{array}$ & 219.5 & $\begin{array}{c}208 . \\
7\end{array}$ & 55.87 & 50.87 & 688.4 & 679.7 \\
\hline $\begin{array}{l}T_{5}: 100 \% \text { RDF, } \\
150: 75: 75 \mathrm{~kg} / \mathrm{ha}\end{array}$ & 210.9 & $\begin{array}{c}184 . \\
6\end{array}$ & 37.22 & 34.22 & 670.7 & 665.2 \\
\hline SEm \pm & 8.78 & 6.90 & 1.80 & 1.20 & 0.81 & 0.83 \\
\hline CD@5\% & 27.05 & $\begin{array}{c}21.2 \\
8\end{array}$ & 5.04 & 3.60 & 2.49 & 2.56 \\
\hline
\end{tabular}


Table.4 Available micronutrient status of soil as influenced by farming systems (after $11 \mathrm{yrs)}$

\begin{tabular}{|c|c|c|c|c|c|c|c|c|}
\hline \multirow[t]{2}{*}{ Treatments } & \multicolumn{2}{|r|}{$\mathbf{F e}$} & \multicolumn{2}{|r|}{ Mn } & \multicolumn{2}{|r|}{$\mathbf{Z n}$} & \multicolumn{2}{|r|}{$\mathbf{C u}$} \\
\hline & $0-20 \mathrm{~cm}$ & $20-40 \mathrm{~cm}$ & $0-20 \mathrm{~cm}$ & $20-40 \mathrm{~cm}$ & $0-20 \mathrm{~cm}$ & $20-40 \mathrm{~cm}$ & $0-20 \mathrm{~cm}$ & $20-40 \mathrm{~cm}$ \\
\hline $\begin{array}{l}\mathrm{T}_{1}: 100 \% \mathrm{~N} \\
\text { through organics }\end{array}$ & 7.43 & 6.63 & 4.43 & 3.66 & 0.73 & 0.38 & 0.56 & 0.55 \\
\hline $\begin{array}{l}\mathrm{T}_{2}: 75 \% \mathrm{~N} \\
\text { through organics }\end{array}$ & 7.32 & 5.97 & 4.22 & 3.45 & 0.51 & 0.31 & 0.51 & 0.43 \\
\hline $\begin{array}{l}\mathrm{T}_{3}: 50 \% \mathrm{~N} \\
\text { through organics } \\
\& 50 \% \mathrm{~N} \text { through } \\
\text { inorganic }\end{array}$ & 6.73 & 6.00 & 4.34 & 3.50 & 0.66 & 0.25 & 0.54 & 0.47 \\
\hline $\begin{array}{l}\mathrm{T}_{4}: 100 \% \mathrm{~N} \\
\text { through in- } \\
\text { organics and FYM } \\
\text { @ } 7 \mathrm{t} / \mathrm{ha}\end{array}$ & 6.77 & 5.86 & 4.01 & 3.44 & 0.49 & 0.28 & 0.46 & 0.43 \\
\hline $\begin{array}{l}T_{5}: 100 \% \text { RDF, } \\
150: 75: 75 \mathrm{~kg} / \mathrm{ha}\end{array}$ & 7.02 & 6.31 & 4.38 & 3.51 & 0.67 & 0.32 & 0.54 & 0.52 \\
\hline SEm \pm & 0.38 & 0.24 & 0.22 & 0.14 & 0.06 & 0.04 & 0.05 & 0.05 \\
\hline CD@5\% & 1.18 & 0.75 & 0.70 & 0.45 & 0.18 & 0.13 & 0.16 & 0.16 \\
\hline
\end{tabular}

Table.5 Microbial population and enzymatic activity of soil as influenced by farming systems

\begin{tabular}{|c|c|c|c|c|c|c|}
\hline Treatment & $\begin{array}{c}\text { Bacteria } \\
\text { CFU g-1 } \\
\text { x10 }\end{array}$ & $\underset{\text { CFUg }^{1} \times 10^{3}}{\text { Fungi }}$ & $\begin{array}{c}\text { Actinomycetes } \\
\text { CFU } \\
\mathbf{g}^{-1} \times 10^{7}\end{array}$ & $\begin{array}{c}\text { Dehydrogenase } \\
\mu \mathrm{g} \\
\operatorname{TPF}^{-1} \mathbf{d}^{-1}\end{array}$ & $\begin{array}{c}\text { Alkaline } \\
\text { phosphatise } \\
\mu \mathrm{g} \text { PNP g }^{-1} \mathbf{h}^{-1}\end{array}$ & $\begin{array}{l}\text { Glycosidase } \\
\mu \mathrm{g} \mathrm{NH} 4^{+} / \mathrm{g}\end{array}$ \\
\hline $\begin{array}{l}\mathrm{T}_{1}: 100 \% \mathrm{~N} \\
\text { through } \\
\text { organics }\end{array}$ & 3.80 & 3.65 & 3.87 & 70.0 & 117.5 & 32.5 \\
\hline $\begin{array}{l}\mathrm{T}_{2}: 75 \% \mathrm{~N} \\
\text { through } \\
\text { organics }\end{array}$ & 3.77 & 2.95 & 3.85 & 50.5 & 101.0 & 25.0 \\
\hline $\begin{array}{l}\mathrm{T}_{3}: 50 \% \mathrm{~N} \\
\text { through } \\
\text { organics \& } 50 \\
\% \mathrm{~N} \text { through } \\
\text { inorganic }\end{array}$ & 2.52 & 2.87 & 3.75 & 45.5 & 74.5 & 19.2 \\
\hline $\begin{array}{l}\mathrm{T}_{4}: 100 \% \mathrm{~N} \\
\text { through in- } \\
\text { organics and } \\
\text { FYM @ } 7 \mathrm{t} / \mathrm{ha}\end{array}$ & 2.82 & 2.72 & 3.77 & 33.2 & 71.5 & 19.0 \\
\hline $\begin{array}{l}\mathrm{T}_{5}: 100 \% \mathrm{RDF}, \\
150: 75: 75 \mathrm{~kg} / \mathrm{ha}\end{array}$ & 1.50 & 1.35 & 3.65 & 35.7 & 58.2 & 17.2 \\
\hline SEm \pm & 0.07 & 0.29 & 0.03 & 1.51 & 1.64 & 0.66 \\
\hline CD@5\% & 0.21 & 0.90 & 0.09 & 4.67 & 5.07 & 2.05 \\
\hline
\end{tabular}


Fig.1 The organic carbon content of surface soil as influenced by farming systems

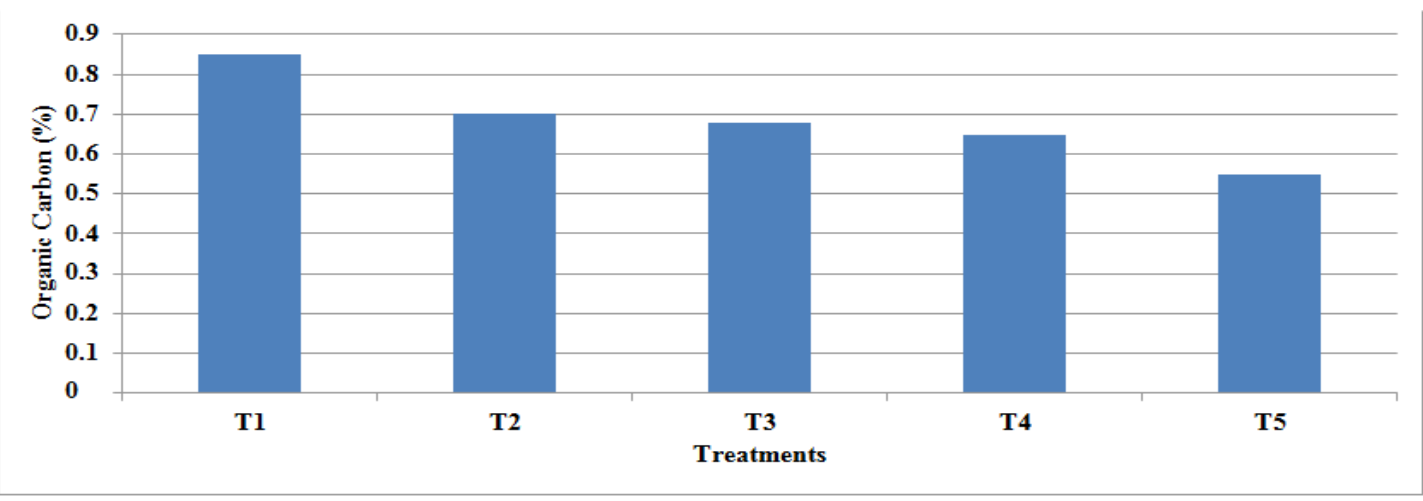

Fig.2 The major nutrient status of surface soil as influenced by farming system

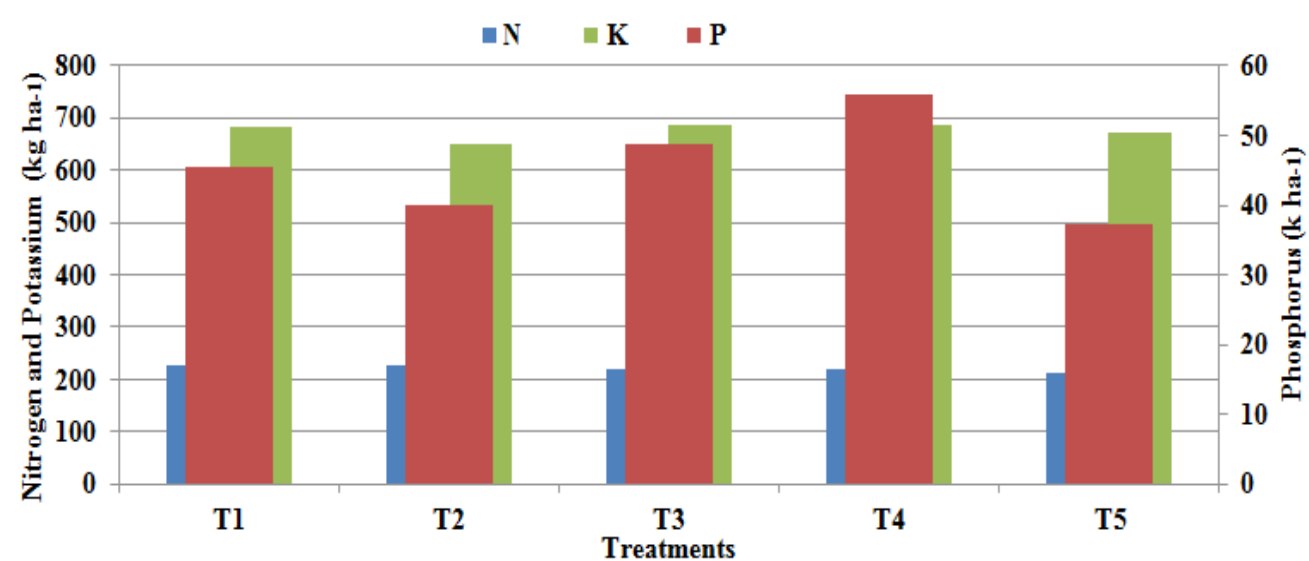

\section{Legend}

T1: $100 \% \mathrm{~N}$ through organics $\mathrm{T} 2: 75 \% \mathrm{~N}$ through organics.

T3: Integrated $\mathrm{N}$ management (50\% $\mathrm{N}$ through organics \& $50 \% \mathrm{~N}$ through inorganic)

T4: $100 \% \mathrm{~N}$ through in-organics and FYM @ $7 \mathrm{t} \mathrm{ha}^{-1}$

T5: $100 \% \mathrm{RDF}, 150: 75: 75 \mathrm{~kg} \mathrm{ha}^{-1}$

Fig.3 Bacterial population of surface soil as influenced by farming system

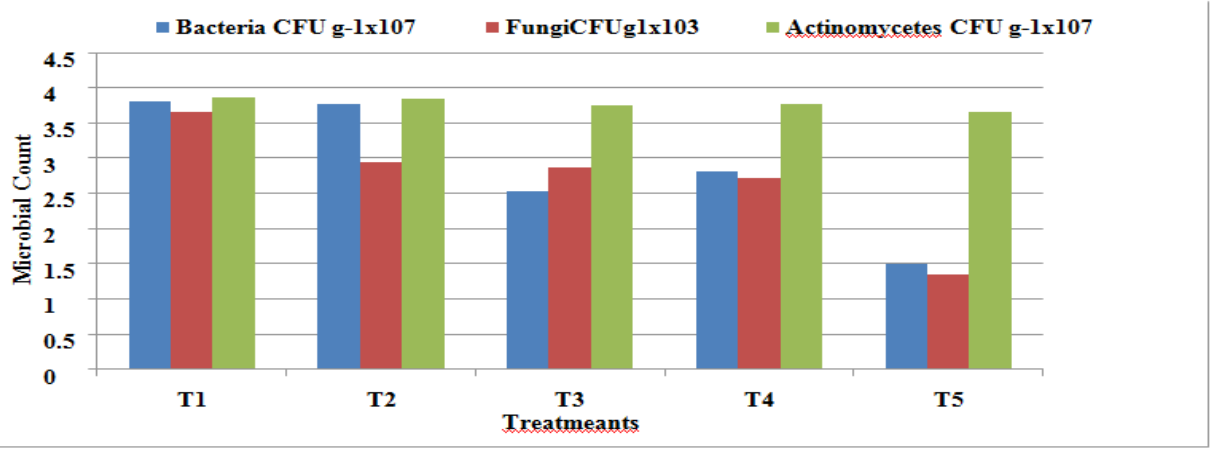


Fig.4 Enzyme activity of surface soil as influenced by farming system

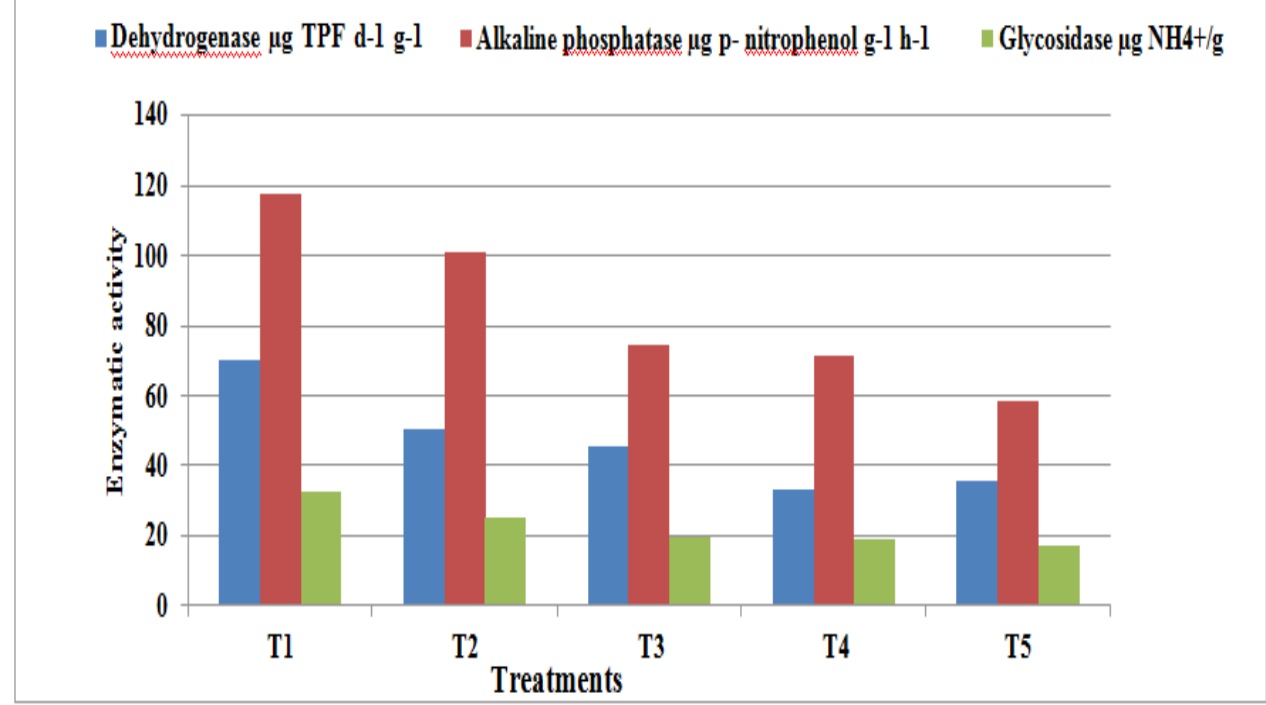

T1: $100 \% \mathrm{~N}$ through organics; T2: $75 \% \mathrm{~N}$ through organics; T3: Integrated $\mathrm{N}$ management $(50 \% \mathrm{~N}$ through organics \& $50 \% \mathrm{~N}$ through inorganic); T4: $100 \% \mathrm{~N}$ through in-organics and FYM @ $7 \mathrm{t} \mathrm{ha}^{-1}$

T5: $100 \%$ RDF, 150: 75:75 $\mathrm{kg} \mathrm{ha}^{-1}$

\section{Enzyme activity}

Significant difference was noticed among the treatments in respect of enzyme activity, namely, dehydrogenase, phosphatase and glycosidase activity of soil (Table 5 and fig.4). The activity of dehydrogenase $(70.3 \mu \mathrm{g}$ $\mathrm{TPF} / \mathrm{g} /$ day $)$, phosphatase $(117.5 \mu \mathrm{g} \mathrm{PNP/g} / \mathrm{h})$ and glycosidase (32.5 $\mu \mathrm{g} \quad \mathrm{NH} 4 / \mathrm{g})$ was significantly higher in the treatments that received 100 per cent nitrogen through organic materials compared to that received 100 per cent nitrogen through inorganic source $(35.7 \mu \mathrm{g} \mathrm{TPF} / \mathrm{g} /$ day, $55.2 \mu \mathrm{g} \mathrm{PNP} / \mathrm{g} / \mathrm{h}$ and $17.2 \mu \mathrm{g} \mathrm{NH}_{4} / \mathrm{g}$, respectively). The results of the present study are very close to the observations made by Krishnakumar et al. (2005) who showed that application of FYM + Neem Cake@90 kg N ha ${ }^{-1}$ recorded highest urease, dehydrogenase activity and the phosphatase activity in the treatment receiving FYM + Neem Cake + Azolla. This might be due to higher organic manure application which would have favoured more microbial populations ultimately more enzyme activity. Similarly, Ramesh et al., (2010) came out with the results that dehydrogenase, alkaline phosphate, and microbial biomass carbon are higher in organic soils by $52.3 \%, 28.4 \%$, and $34.4 \%$ respectively, as compared to conventional farms.

\section{References}

Acharya, C.L., Bisnoi, S. K. and Yaduvanshi, H. S., 1988, Effect of long-term application of fertilizers and organic and inorganic amendments under continuous cropping on soil physical and chemical properties in an Alfisol. Indian J. Agril. Sci., 58: 509- 516.

Bharadwaj, V. and Omanwar, P. K., 1994, Longterm effect of continuous rotational cropping and fertilization on crop yields and soil properties-II. Effect on EC, pH, organic matter and available nutrients of soil. $J$. Indian Soc. Soil Sci., 42: 387-392.

Bhatia, K. S. and Shukla, K. K., 1982, Effect of continuous application of fertilizers and manure on some physical properties of eroded alluvial soil. J. Indian Soc. Soil Sci., 30: 33- 
36.

Bellakki, M. A. and Badanur, V. P., 1994, Effect of crop residues incorporation on physical and chemical properties of a Vertisol and yield of sorghum. J. Indian Soc. Soil Sci., 42(2): 533535.

Bhandari, A. L., Anil Sood, Sharma, K. N. and Rana, D. S., 1992, Integrated nutrient management in a rice-wheat system. J. Indian Soc. Soil Sci., 40: 742-747.

Boydaş, M. G. and Turgut, N., 2007, Effect of tillage implements and operating speeds on soil physical properties and wheat emergence. Turkish J. Agril and Forestry., 31:399-412.

Gupta, A. P., Antil, R. S. and Narawal, R. P., 1988, Effect of farm yard manure on organic carbon, available $\mathrm{N}$ and $\mathrm{P}$ content of soil during different periods of wheat growth. $J$. Indian Soc. Soil Sci., 36: 269-273.

Jackson, M. L., 1973, Soil Chemical Analysis, Prentice Hall of India Pvt. Ltd., New Delhi, pp. 498.

Jadhav, S. B., Jadhav, M. B., Joshi, V. A. and Jagatap, P. B., 1993, Organic farming in the light of reduction in use of chemical fertilizers. Proc. 43rd Annual Deccan Sugar Technology Association, Pune, Part I, pp. SA53-SA65.

Katsvairo, T., Cox, W. J. and Van Es, H., 2002, Tillage and rotation effects on soil physical characteristics. Agron. J., 94: 299-304.

Kaushik, R. D., Verma, K. S., Dang, Y. P., Sharma, A. P., Verma, S. I. and Pannu, B. S., 1984, Effect of nitrogen and farm yard manure on yield of crops, nutrients uptake and soil fertility in paddy-wheat rotation. Indian $J$. Agric. Res, 18: 73-78.

Krishnakumar, S., Saravanan, A., Natarajan, S. K., Veerabadran, V. and Mani, S., 2005, Microbial population and enzymatic activity as influenced by organic farming. Res. J. Agric. Bio Sci., 1(1): 85-88.

Pawar, R. B., 1996, Dynamics of earthworm soil plant relationship in semi-arid tropics. Ph. D. Thesis, Univ. Agric. Sci., Dharwad.

Phule, K. L., 1993, Vermicompost farming practice in Maharashtra - a case study of sugarcane farming on wasteland. In : Extended Abstracts of Congress on Traditional Science and Technologies of India, 28th November to 23rd December, 1993, Bombay, pp. 10-15.

Piper, C.S., 1966, Soil and Plant Analysis. Academic Press, New York, pp. 367.

Ramesh, N. D., Halepyati, A. S. and Pujari, B. T., 2010, Effects of organic manures and fertilizer levels on seed yield and economics of safflower. Karnataka. J. Agric. Sci., 21(1):104-105.

Sadasivam, S. and Manickam, A., 1992, Biochemical methods for agricultural sciences, wiley eastern limited, pp. 46-49.

Sharma, M. P., Bali, S. V. and Gupta, D. K., 2000, Crop yield and properties of inceptisol as influenced by residue management under ricewheat cropping sequence. J. Indian Soc. Soil Sci., 48(3): 506-509.

Sinha, B. K., Sarkar, A. K. and Srivastava, B. P., 1983, Effect of continuous application of manure and fertilizer on different forms of aluminium in an acid soil. J. Indian Soc. Soil Sci., 31: 632-634.

Tandon, H. L. S., 1987, Phosphorus research and agricultural production in India, FDCO, New Delhi.

Venkateshwaralu, J., 1983, Nutrient supply from organic sources. Dryland Agricultural Research in India. Thrust in the eighties All India Co-ordinated Research Project for Dryland Agriculture, pp: 54-60.

\section{How to cite this article:}

Praveen Karikatti, S. N. Bhat, S. R. Balanagoudar, B. G. Mastanareddy, H. Veeresh and Satyanarayana Rao. 2020. Long term effect of Organic, Integrated and Inorganic Nutrient Management Practises on Soil Properties in a Vertisol. Int.J.Curr.Microbiol.App.Sci. 9(01): 2317-2326. doi: https://doi.org/10.20546/ijcmas.2020.901.263 